\title{
POST DISASTER WASTE MANAGEMENT STRATEGIES IN DEVELOPING COUNTRIES: CASE OF SRI LANKA
}

\author{
Gayani KARUNASENA $1 \bowtie$, Dilanthi AMARATUNGA ${ }^{2}$, \\ Richard HAIGH ${ }^{3}$ and Irene LILL ${ }^{4}$
}

1 Department of Building Economics, Faculty of Architecture, University of Moratuwa, 10400 Moratuwa, Sri Lanka

E-mail: gayani@becon.mrt.ac.lk

2 School of the Built Environment, The University of Salford, Maxwell Building - $4^{\text {th }}$ Floor, Salford, Greater Manchester, M5 4WT, UK

E-mail: R.D.G.Amaratunga@salford.ac.uk

3 School of the Built Environment, The University of Salford, Maxwell Building - $4^{\text {th }}$ Floor, Salford, Greater Manchester, M5 4WT, UK

E-mail:R.P.Haigh@salford.ac.uk

4 Department of Building Production, Tallinn University of Technology, Ehitajate tee 5, 19086 Tallinn, Estonia

E-mail: irene.lill@ttu.ee

Received 16 March 2009; accepted 29 April 2009

\begin{abstract}
Disasters cause substantial damage around the world. This causes serious environmental and economic burden on normal living conditions, reconstruction and general waste collection processes. Within this context, waste management has emerged as a critical issue in responding to a disaster. Thus, this paper addresses post disaster waste management strategies adopted in developing countries and applicability of best global practices in respect of challenges encountered. Comprehensive literature review and field survey among national level institutes in Sri Lanka were conducted to gather information and semi-structured interviews were used as a method of data collection. The findings revealed that strategies, issues and challenges are varying according to type of disaster, magnitude, location, country etc. Further, poor implementation of prevailing rules and regulations; poor standards of local expertise and capacities, inadequate funds, lack of communication and coordination are identified as key issues encountered.
\end{abstract}

Keywords: Disaster; Building waste; Waste management strategies; Developing countries; Sri Lanka

\section{INTRODUCTION}

Disasters, which are occurring in an increasing frequency in the world with devastating impacts (Shaw, 2006), have been defined in many ways depending on their characteristics and degrees of damages (Shakuf, 2007). According to the definition of Center for Research on the Epidemiology of Disasters (CRED) (CRED, 2007) "disaster is a situation or event, which overwhelms local capacity, necessitating a request to national or international level for external assistance; an unforeseen and often sudden event that causes great damage, destruction and human suffering". Emergency Events Database (EM-DAT, 2008), states that 
last eight years $(2000-2008)$ have seen 1.5 million people killed, more than 2 billion million people affected and about US $\$ 715$ billion in economic losses caused by disasters. Out of people affected by disasters, almost $97 \%$ were affected by hydro meteorological (weather related) hazards, which also caused $60 \%$ of total economic losses caused by disasters (Shaw, 2006). CRED (2007) reveals that frequency of disasters and their effects seems to be increasing within last few decades.

According to Shaw (2006) impacts of those disasters, whether natural or man made, not only have human dimensions, but also environmental dimensions as well. Casualties including deaths, injured and misplaced people are the major physical impacts or human dimensions of any kind of a disaster. Property damages, collapsing of buildings, infrastructures and crop destruction are some further critical matters of a disaster situation (Shaw, 2006; Lindell and Prater, 2003). Tremendous amount of waste generation is a one grave consequence of all of above mentioned effects which should attract the society's attention highly. Pelling et al. (2002) emphasis that among the most adverse consequences of a disasters such as deaths, injuries, physical damages, disruption to economy and social disruption, the third potential loss of a disaster is physical damages which are the destruction of buildings and infrastructure creating enormous amount of building waste. Managing these wastes is very much hard since disaster wastes are mixed and difficult to separate (Kobayashi, 1995).

This causes serious environmental and economic burden on normal living conditions, reconstruction as well as on general municipal waste collection processes (UNEP, 2005; Bandara and Hettiarachchi, 2003). Within this context, waste management and disposal has emerged as a critical issue in responding to a disaster in any country whether developing or developed. Further, disasters are so close- ly intertwined with environment that proper environmental management and governance is essential for long term peace, stability and security in disaster prone countries, particularly, in developing countries where affected communities rely heavily on natural resources for survival.

This paper attempts to document waste management strategies, issues and challenges in disaster building waste management in developing countries, with special emphasis on Sri Lanka. Further, the paper will seek to identify the feasibility of mapping the best practices of waste reduction strategies used globally for future disasters in developing countries.

\section{RESEARCH METHODOLOGY}

Comprehensive literature review was carried out to identify waste management strategies, issues and challenges in disaster waste management at post disaster scenario. Secondary data includes more information pertaining to Asian Tsunami 2004 since this is the single event disaster that recorded highest number of deaths, damaged houses and affected families during the recent past in many developing countries like Sri Lanka, Thailand, Maldives and Indonesia (Joint Report, 2005; Hettiarachchi, 2004).

Field Survey was restricted to national level organizations related to waste management in Sri Lanka due to inability of author to conduct field surveys in other countries. Semi structured interviews were conducted with government and non-government organizations to identify waste management strategies adopted and their successfulness.

The structure of the paper consists of disasters during past, post disaster waste management practices, issues and challenges in disaster waste management, comparative discussions and conclusions to the paper. 


\section{DISASTERS DURING PAST (2004 ONWARDS)}

The world is facing an increasing frequency and intensity of disasters - natural and manmade - that has had devastating impacts. Emergency Events Database (EM-DAT, 2008), a global disaster database maintained by the CRED in Brussels, records more than 600 disasters globally, each year. According to the World Disaster Report 2000, over $80 \%$ of the world's climate-related disasters occurred in Asia (IFRC and RCS, 2000). Among those, in May 2008, an earthquake in Sichuan, Gansu and Yunnan provinces in Western China and Cyclone Nargis in Myanmar killed more than 69,000 people and inflicted billions of dollars of damages (Stone, 2008). While number of geophysical disasters such as earthquakes, Tsunamis etc, has remained steady, number of hydro-meteorological (weather related) events such as droughts, windstorms, floods, etc., has more than doubled. This is linked to climatic change and scientists predict global warming to result in more extreme weather patterns, providing for stronger and increasingly violent weather patterns. Therefore, challenges of recovery from natural disasters will be with us

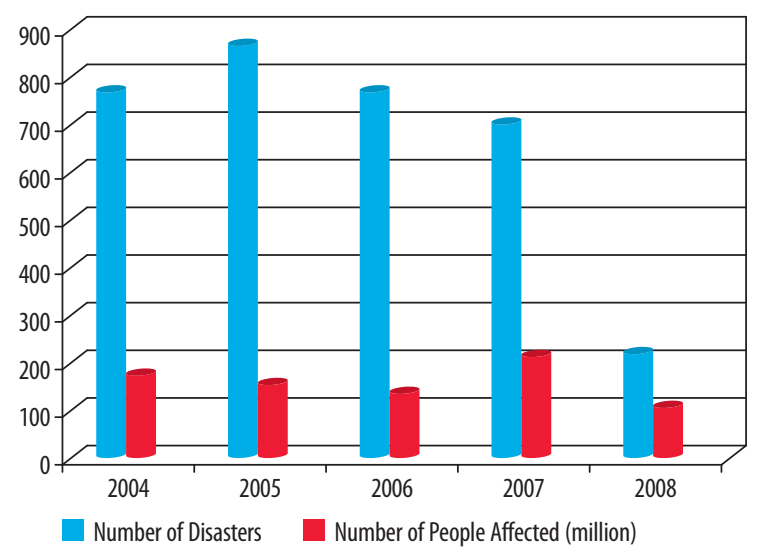

Figure 1. Number of disasters and people affected in the world during last five years

(Source: EM-DAT, 2008) for an unforeseeable future (Helmer and $\mathrm{Hi}$ horst, 2006).

According to World Bank estimates in 1998, natural disasters killed over 50,000 people and destroyed US $\$ 65$ billion worth of property and infrastructure. The United Nations Human Settlements Programme (UNHSP) notes that in the first half of 2001 alone, natural disasters caused over US $\$ 24$ billion damages globally. At the same time, over 60 million civilians were affected by some 30 conflicts in various parts of the world. The Figure 1 illustrates the number of disasters and peoples affected in during the past five years (2004-2008), according to EM-DAT (2008).

According to above, although more disasters occurred in 2005, impacts on humans were higher in 2007 although number of disasters was less when compared to other years. For example, statistics of the major Tsunami that occurred on $26^{\text {th }}$ of December 2004, in the Asian region killing nearly 250,000 people around the Indian Ocean indicates a single event which had higher impact than other disasters that happened during the year. Most of these disaster-related deaths occurred in developing countries and affected poorest people most severely. It also appears that same countries suffer from disasters repeatedly. For example, in Mexico, natural disasters claimed 10,000 lives and cost US $\$ 6.5$ billion in 19802000 , and in Indonesia, natural disasters claimed more than 165,000 lives and cost US $\$ 5$ billion during 2000- 2006 (Stone, 2008). It also appears that occurrence of disasters with severe impacts is on the increase. It is estimated that of the 100 most expensive natural disasters of the 20th century, 65 occurred in the 1990s, 25 in the 1980 s and 10 in the 1970s, and much fewer in the previous decades (Du Plessis, 2001, cited Ofori, 2004). It is apparent that frequency and impact of disasters is greater in developing countries. Moreover, these nations are among those which tend to 
be repeatedly affected by various types of disasters. Furthermore, developing countries are less able to cope with effects of such occurrences. There is evidence that impacts of disasters depend not only on their numbers but also on other factors such as types of disasters, magnitude, location etc.

In the case of developing countries the droughts, landslides, storms and floods are common natural disasters while terrorism, violence, civil conflicts, explosions and industrial accidents are man-made disasters that affect communities (Jayaweera, 2006). In addition, the Tsunami that occurred in 2004 is recorded as an event that vastly affected costal communities of various developing countries in Asia during the recent past.

\subsection{Disasters in Sri Lankan context}

Sri Lanka is prone to natural disasters commonly caused by floods, cyclones, landslides, droughts and coastal erosion for generations with increasing losses of life and property (Jayawardane, 2006). Earthquakes have been recorded over the past 400 years and the country is also exposed to various human-induced hazards resulting from deforestation, indiscriminate coral, sand and gem mining and industrial pollutants (DMC, 2005).

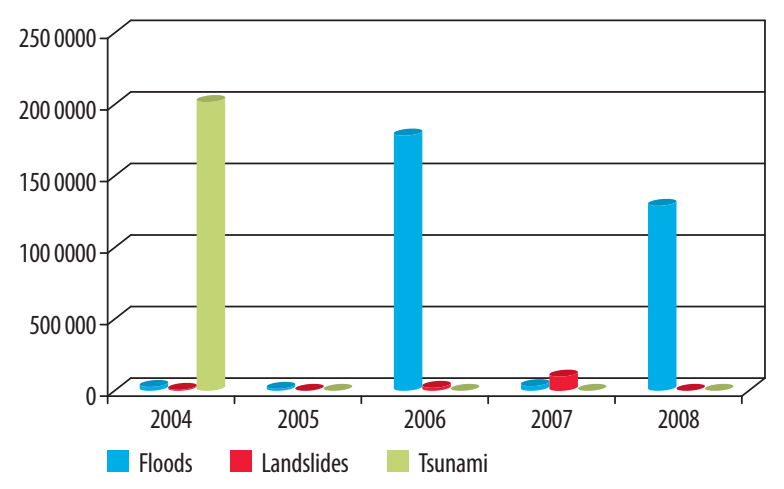

Figure 2. Number of families affected by different disasters during 2004-2008 (Source: DMC, 2008)
The Figure 2 illustrates, according to the National Disaster Management Centre report (DMC, 2008), disasters which occurred island wide during the period of 2004-2008.

Floods are the more critical and frequent disaster that occurred during the recent past. It caused immense damage to affected areas, interrupting all economic and social activities. It is also reported that there are tremendous damages to infrastructure facilities in affected areas where around 315,447 families were affected and 3256 houses were damaged partially or completely. Landslide is a common and seasonal disaster in Sri Lanka and according to DMC (2008), in 2007 landslide caused more impacts than floods where around 13,466 families were affected and 1047 houses were damaged partially or completely. Sri Lanka has been extremely hard-hit in terms of loss of life, infrastructure, and economic assets by the 2004 Tsunami which is widely acknowledged as the largest, most devastating natural catastrophe in the recent history of the country. According to the joint report of the Government of Sri Lanka and Joint Development Partners in December 2005, within a short period it claimed 35,322 lives, injured 21,441, orphaned 1,500 children and left many families without spouses (Joint Report, 2005). It heavily damaged 78,199 houses and partially damaged 48,911 more houses. In addition, it states that two thirds of the country's coastline was affected with many damages inflicted on roads, bridges, buildings, railways and other transport systems, ports and harbors, electricity and water supply systems, communication lines, markets, town and private properties. Since the coastline of Sri Lanka is heavily populated, where most of industrial and commercial activities take place, the country's economy was seriously affected (Subasinghe, 2005). 


\section{POST DISASTER WASTE MANAGEMENT}

The debris generated by most severe disasters, overwhelm existing solid waste management facilities or force communities to use disposal options that otherwise would not be acceptable (EPA, 2008). This waste problem arising from disasters are grave and should attract much social attention due to adverse effects on water quality, air quality and noise, flora and fauna, visual impacts and socio economy (Petersen, 2004). European Commission has also identified waste management as a key issue to be addressed among several dimensions in rehabilitation of environment in post emergency relief (EC, 2006). According to Aung and Arias (2006) the problem of waste can be addressed in a number of ways at community and governmental levels. Therefore, proper planning is of utmost importanance to reduce future vulnerabilities and to improve long-term sustainability (Shaw and Sinha, 2003).
The measures aiming at controlling disaster waste generation such as building regulations and codes need to be introduced at mitigation phase of disaster management cycle, as illustrated at Figure 3. The management of debris is involved at the recovery stage as debris generated through damaged buildings need to be collected, transported, reused, recycled, land filled or disposed. Rafee et al. (2008) indicated that disposal of debris is one of the main challenges of a disaster recovery operation. Therefore, a proper waste management plan should be established at the recovery stage. At the reconstruction phase, construction waste is produced by reconstruction work which is usually clean and relatively uncontaminated which creates specific opportunities for recycling.

The Environment Protection Agency (EPA) in USA in their report (EPA, 2008) has identified several items which are generated as waste at most post disaster circumstances as soil and sediments, building rubble, vegetation,

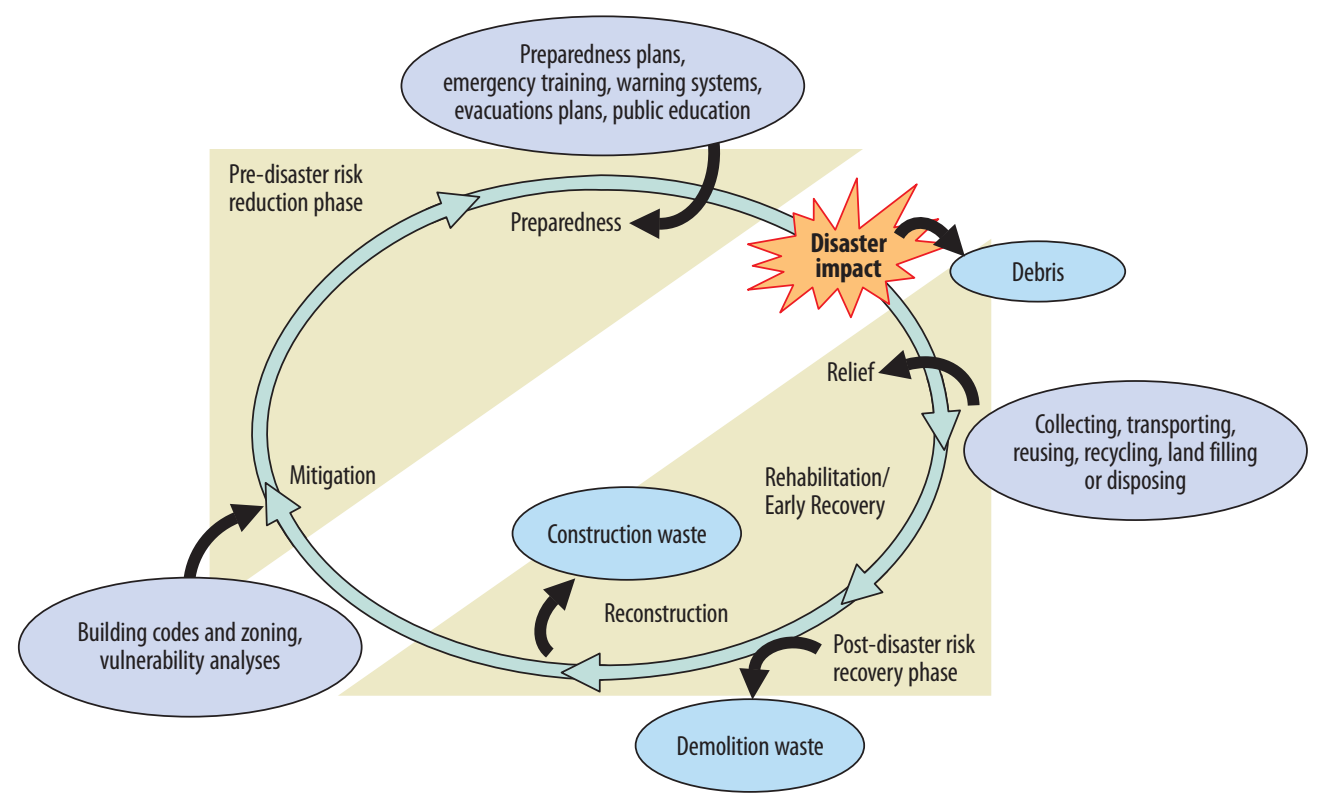

Figure 3. Relationship of disaster management cycle with disaster waste management (Source: DMC, 2005) 
personal effects, hazardous material, mixed domestic and clinical wastes and, all too often, human and animal remains. These wastes represent a risk to human health from biological sources, chemical sources and physical sources (EPA, 2008). Further findings reveled that generation of waste is also varying according to the type of disasters. Among these, building waste is a common type of waste with almost all types of disasters other than automobiles, furniture, vegetative debris, mixed metals, ash and charred wood waste and other debris.

Kobayashi (1995) classified the disaster waste as: rubble and other waste accumulated on roads, demolition and dismantling waste of buildings, bulky waste and raw materials, items in processes or other substances. In 2004, Baycan refined the classification in a more comprehensive manner as: recyclable materials (concrete, masonry, wood, metal, soil and excavated material), non recyclable materials (household inventory, organic materials, and other inert materials) and hazardous waste (asbestos, chemicals) (Baycan, 2004). Kourmpanis et al. (2008) has pointed out that building waste is considered to be one of the priority waste streams and appropriate actions need to be taken with respect to its effective management. There are significant numbers of possible technical solutions and the next sections will address them in detail.

\section{POST DISASTER WASTE MANAGEMENT STRATEGIES AND MODELS}

Building waste is derived from both the damaged build environment as well as from the subsequent relief and rehabilitation efforts. Considering the often large quantities of such solid wastes generated, early action within relief and rehabilitation programs is required to manage them in an environmentally sound manner. Managing these wastes is very much hard because, not as ordinary construc- tion wastes, disaster wastes are mixed and difficult to separate them (Kobayashi, 1995). Management of these waste streams becomes a considerable challenge for national and local institutions during rehabilitation and reconstruction stages (Baycan and Petersen, 2002). Further, it emphasis on importance of designing early stage strategies for building waste management at post disaster scenarios and following key requirements were introduced which need to be identified prior to designing a strategy:

- Prior to disaster management procedure of handling the building waste stream, disposal sites and possible recyclable materials.

- The quantity of building waste generated including composition and source.

- The capacity of local areas to handle building waste, including number and types of trucks, condition of disposal sites and opportunities to recycle.

- The scope of reconstruction works expected in order to identify opportunities for utilization of recycled building waste.

- An understanding of governmental and local authority structures in order to place the responsibility for building waste management at the right office.

The underlying goals of the strategy should be anchored in the national waste management and environmental policies, as well as taking into account the actual ground situation. In addition, the strategy should provide opportunities for further development of these policies.

\subsection{Post disaster waste management strategies}

Waste management is a discipline associated with control of generation of waste, storage, collection, transfer and transport, processing, reuse and recovery and disposal of solid waste in accordance with best principles of public health, economics, engineering, conservation 
of nature, aesthetics and environmental, while considering the general public attitude. Following session provides details of waste management strategies related to each discipline of waste management defined above.

\subsubsection{Controlling of generating building waste}

The initial step of a waste management strategy should be controlling of generating building waste consequent to a disaster. Although total prevention may not be feasible, some measures need be taken to help reduce generation of debris. The EPA in USA in their report (EPA, 2008) indicated that current building codes and planning need to be evaluated to determine whether it will allow a community to withstand disasters prone to that area. Moreover, it has disclosed that many states and communities have compiled hazard mitigation plans that discuss preventative measures aimed at reducing generation of disaster debris. Examples are educating home owners about how to strengthen their homes to resist damages from disasters. Other means of controlling waste generation is the reuse of waste. According to the Strategy for Sustainable Construction and Demolition Waste Management in Galle, Sri Lanka (COWAM, 2008), building waste materials like bricks, aggregate, steel and timber can be reused without reprocessing. The countries like Indonesia which was severely devastated by the Tsunami, are having successful waste reuse and recycling plans (EC, 2006).

\subsubsection{Collecting waste}

According to Federal Emergency Management Agency (FEMA) (FEMA, 2007), debris removal operations generally occur in two phases as initial debris clearance activities necessary to eliminate life and safety threats and debris removal activities as a means of recovery. The transition period from initial clearance activities to debris removal depends on the magnitude of disaster impact. Typically, the debris removal recovery phase begins after the emergency access routes are cleared and police, firefighters and other first responders have necessary access. Further, FEMA (2007) has proposed two methods of building debris collection: curbside collection (mixed debris collection, source-segregated debris collection) and collection centers.

\subsubsection{Transporting waste to relevant sites}

The most common suggestion of EPA (2008) for a better debris management is to pre select temporary sites that can be used for storing, sorting and processing of debris. These sites can be used to temporarily store debris before transferring to another recycling plant. The site should be selected considering the planned activities such as storing, sorting and processing as well as access by heavy equipment, protection of environmentally sensitive areas and logistical efficiency. In a disaster situation, it may not be practical to employ a system of waste separation due to amount of debris and time and labor it would require (Treloar et al., 2003; Bekin et al., 2007). According to Selvendran and Mulvey (2005), waste separation system becomes impractical at a post disaster situation as cleanup and recovery became the first priority.

\subsubsection{Processing of waste}

According to EPA (2008), the waste can be processed in two means as composting and recycling. The composting is most appropriate in case of mixed debris in situations where segregation is costly. The biodegradable materials can be easily composted by means of home composting or centralized composting due to the space problem (Practical Action, 2008). Among the vigorous amount of building debris generated by a disaster, there is an opportu- 
nity to recycle significant types of materials such as concrete (crushing, pre sizing, sorting, screening and contaminant elimination, metal (ferrous, non ferrous and aluminum), timber (solid softwood) and rubber materials (CMRA, 2008; Eerland, 1995; The Kindred Association, 1994). Recycling should be processed according to market specifications of each material and therefore, it needs specific plant equipments.

\subsubsection{Disposing of waste}

After reusing and recycling, the remaining debris should be disposed in landfills properly and safely. In order to perform this in an environmental friendly manner, the volume of disposing debris should be minimized up to the maximum possible extent by using incineration (uncontrolled open air incineration, controlled open air incineration, air curtain pit incineration) and chipping and grinding (rubber and metal materials) (FEMA, 2007; EPA, 2008).

As discussed above, reduction is the best and most efficient method for minimizing generation of waste. It will reduce costs associated with handling and managing of waste disposal processes. Reuse is the most sought-after option after reduction because a minimum of processing and energy use is achieved through reusing waste materials. Since landfill volumes are rapidly decreasing in many countries, many communities are considering burning their waste. But this is not a very good way of managing waste since it can make inevitable problems to the environment due to air pollution. According to C\&D waste management hierarchy by Peng et al. (1997) landfill is the lowest in the hierarchy. Leachate, off-gassing, and potential groundwater contamination are typical problems of landfills (Peng et al., 1997). According to author's opinion it should be considered only when all other options have been exhausted.

The Table 1 illustrates the various waste management strategies adopted during past disaster situations.

The Table 1 reveals that the most commonly adopted strategy for building waste management is implementation of recycle plants although there were various problems arising due to operational barriers. Recycling and reusing of building waste conserve natural resources by replacing them with recovered products which perform the same function. This provides for greater savings by decreased consumption of natural resources such

Table 1. Building waste management strategies in global context

\begin{tabular}{|c|c|c|c|}
\hline Place & Amount & Strategies & Remarks \\
\hline $\begin{array}{l}\text { Marmara } \\
\text { earthquake, } \\
\text { Turkey }\end{array}$ & $\begin{array}{l}13 \\
\text { million } \\
\text { tons }\end{array}$ & $\begin{array}{l}\text { - Recycling plant } \\
\text { - } 17 \text { Dump sites }\end{array}$ & $\begin{array}{l}\text { - High level of reinforcement, bars in the } \\
\text { demolition waste causes operational } \\
\text { problems in plant } \\
\text { - Illegal dumping at coastal line }\end{array}$ \\
\hline $\begin{array}{l}\text { Kobe } \\
\text { earthquake, } \\
\text { Japan }\end{array}$ & $\begin{array}{l}15 \\
\text { million } \\
\text { tons }\end{array}$ & $\begin{array}{l}\text { - Minor proportion recycled } \\
\text { - Majority disposed or land } \\
\text { reclamation }\end{array}$ & $\begin{array}{l}\text { - Separation of recycling material time } \\
\text { consuming and costly }\end{array}$ \\
\hline $\begin{array}{l}\text { Beirut, } \\
\text { Lebanon }\end{array}$ & $\begin{array}{l}4 \text { million } \\
\text { tons }\end{array}$ & - A stationary recycling plant & $\begin{array}{l}\text { - Problems arising with the "cleanliness" } \\
\text { of the demolition waste }\end{array}$ \\
\hline Kosovo & $\begin{array}{l}10 \\
\text { million } \\
\text { tons }\end{array}$ & $\begin{array}{l}\text { - A mobile recycling plant } \\
\text { - Decentralized depots collection } \\
\text { and storage }\end{array}$ & - Spread of damage over a large rural area \\
\hline
\end{tabular}

Source: Baycan and Petersen (2002); de Boer and Sanders (2004). 
as sand, mining, crushed stones or extracting petroleum. Further, it reveals that very few adopted land filling as a strategy for building waste management unlike developing countries. The building waste is increasingly being seen as a valuable source of engineering materials for the reconstruction process after a disaster. The management of building waste offers economic benefits as well, apart from the environmental benefits.

\subsection{Post disaster waste management models}

Disaster waste management models vary according to region and country depending on local conditions. Figure 4 illustrates an internationally recognized solid waste management model produced by United Nation Environment Program (UNEP) in year 2005 (UNEP, 2005). As the initial step, activities of the model should be fully incorporated with legislation and policies established on the basis of environmental protection, solid waste management, waste reduction or avoidance, standard guidelines for land filling disposals, financial sustainability, etc. Further, in this combustion, composting and material recovery (reuse and recycling) has been introduced as waste management strategies (UNEP, 2005). In addition to above, various disaster management models were implemented in various disaster situations in the past, as illustrated below.

Baycan (2004) introduced a model only for demolition waste management based on the experience of Marmara earthquake, Turkey. In Marmara earthquake, rubble was identified as a major building waste. According to the model, initially the rubble was collected and transported to temporary dump sites during emergency period and subsequently transported to recycling or disposing sites. An identified issue of this process is double handling of waste resulting in high transport costs. The key principles of this model are:

- Conservation of natural resources.

- Reduction of quantities of waste for final disposal.

- Minimization of negative environmental impacts caused by waste.

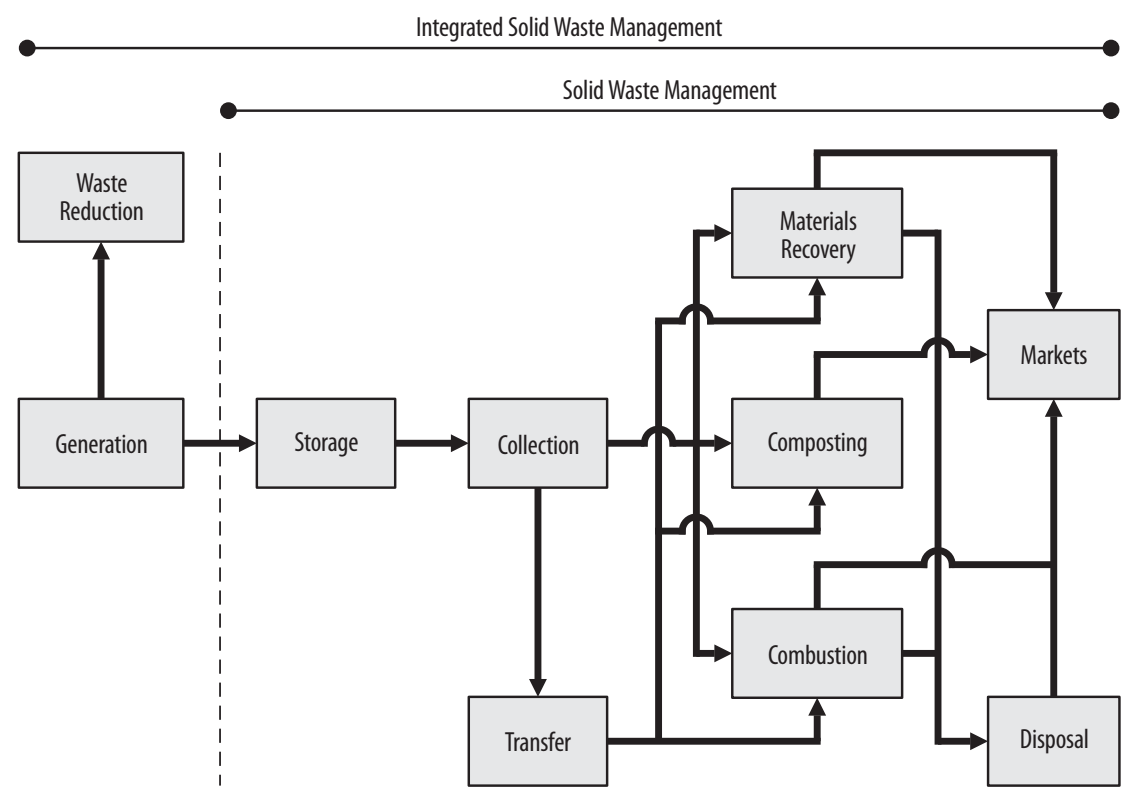

Figure 4. Solid waste management model proposed by UNEP (UNEP, 2005) 


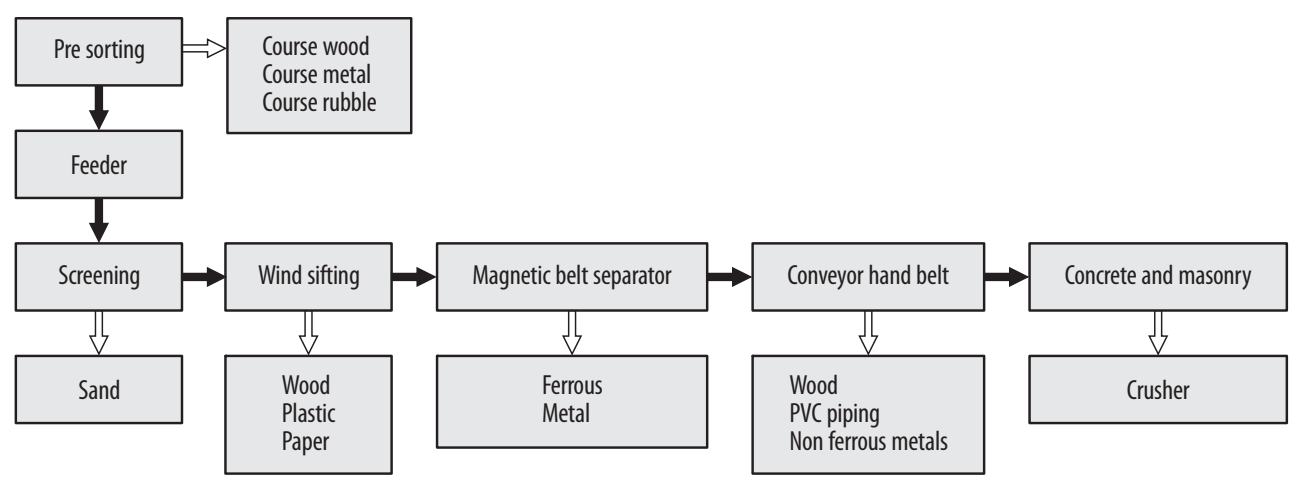

Figure 5. Proposed earthquake waste management plan, Kobe Source: (Eerland, 1995)

Model developed for management of waste of earthquake in Kobe is illustrated at Figure 5 . The priority of the model was given to separation of waste into specific components. Initially the waste was distinguished using separation plants with a capacity of 50 tonnes per hour. Screening, wind sifting, hand picking and belt separators are some technologies of the plant that used to differentiate building materials. Finally, the separated materials were sent to reprocessing and reuse (Eerland, 1995).

Most above models were developed for earthquake disasters since the waste can be easily separated and sent to reprocessing and reuse. Further, these models can be identified as having been successfully implemented in developed countries that have experience in frequent disasters, technology know how, expertise etc. For the model to be successful it must be embraced, coordinated and implemented at national, provincial, regional, municipal, institutional and community levels, too.

\subsection{Post disaster waste management strategies in Sri Lankan context}

In Sri Lanka during recent years several disasters occurred island wide. Among these, floods and landslides were more frequent disasters, which caused less serious waste management issues and were managed by usual municipal and industrial waste management authorities. Unlike floods and landslides, Tsunami created significant quantity of solid wastes which challenged the national and local capacities. According to the UNEP report (UNEP, 2005), in Sri Lanka about 100,000 of houses have been destroyed generating about 450,000 tons of debris by the Tsunami. Further, it reveals that debris were not properly disposed, reused or managed in Sri Lanka. Also, Perera (2003) has revealed that even there is no proper garbage discharge in Sri Lanka and many drains are blocked with garbage, causing health problems. In this context, economical and environmentally sound waste management programmes are essential not only for disaster waste but also for municipal solid waste management. It has been identified that lack of awareness of mechanisms and systems of post disaster waste management is a critical issue of concern. Following Table 2 indicates waste management strategies adopted during last five years in Sri Lanka.

In developing countries most commonly used strategy is illegal open dumping. Uncontrolled dumping of wastes can have a significant negative public health and environmental impacts through leaching of contaminants into soils and groundwater, increased vermin presence, negative odour and visual impacts. In addition, hazardous and healthcare wastes 
Table 2. Building waste management strategies in local context

\begin{tabular}{|c|c|c|}
\hline Type of disaster & Waste management strategies & Remarks \\
\hline Tsunami, 2004 & $\begin{array}{l}\text { - Local government authorities, } \\
\text { volunteers and land owners removed } \\
\text { debris } \\
\text { - Recycling plants were implemented for } \\
\text { building waste in Galle and Ampara } \\
\text { - Some places waste was burned } \\
\text { - Disposed to land filling }\end{array}$ & $\begin{array}{l}\text { - Lack of awareness of waste } \\
\text { management strategies } \\
\text { - Unplanned landfill sites in } \\
\text { environmentally sensitive areas } \\
\text { - Illegal landfill sites } \\
\text { - Lack of capacities } \\
\text { - Inadequate finds } \\
\text { - Lack of coordination }\end{array}$ \\
\hline Floods & $\begin{array}{l}\text { - Open burning process } \\
\text { - Open dumping places } \\
\text { - Land filling }\end{array}$ & $\begin{array}{l}\text { - Illegal dumping on roadsides, vacant } \\
\text { land or river/ stream banks caused } \\
\text { environmental problems }\end{array}$ \\
\hline Landslides & $\begin{array}{l}\text { - Recycling } \\
\text { - Open dumping places } \\
\text { - Land filling }\end{array}$ & $\begin{array}{l}\text { - Collection methods } \\
\text { - Lack of capacity }\end{array}$ \\
\hline
\end{tabular}

Source: Pilapitiya et al. (2006); Peppiatt et al. (2001); Harvey (2005)

dumped openly are a source of potential harm to people, generating an increase in support needed, particularly critical during an emergency phase, and involve a greater amount of financial resources. In case of Sri Lanka, it is a national issue owing to capacity constraints of available landfills of most local authorities, particularly municipal councils. Post disaster waste cannot be overlooked as it occupies a considerable proportion of landfill volume due to demolition waste and boom in construction activities after destruction. One major problem is non-availability of landfills for such a huge volume of debris left over by a massive destruction.

However, in case of the Tsunami, Maldives and Indonesia, with the corporation of UNEP developed a UN Post-Asian Tsunami Waste Management Plan that was launched to remove disaster debris (UNEP, 2005). In the Maldives 16 waste management centers were constructed for waste collection and disposal; preparations were made for construction of further 22 waste management centers and a regional waste management facility. In Indonesia over one million cubic meters of Tsunami waste were cleared and almost one hundred cubes of municipal waste collected through reestablished municipal waste collection systems (EC, 2006).

In many developing countries, building waste is not recovered and reused at its optimum capacity, including Sri Lanka. Most of reusable and recyclable materials are disposed to landfill sites due to insufficient knowledge about recycling (Brodin and Anderson, 2008). Further discussions on above will be forthcoming at following sections of this paper.

\section{SURVEY FINDINGS}

Stakeholders involved in waste management process have important roles to play and this should be linked to resource conservation, environmental protection, sustainable development, health and sanitation issues and disaster preparedness. Within this context, it is important to identify strategies, issues and challenges in post disaster waste management at national level institutes in Sri Lanka as they are responsible for planning and implementing of these strategies. 


\subsection{Stakeholders and their relationship}

Disaster Management Centre (DMC) is the key national level institution established for planning, coordinating and implementing disaster management plans under Disaster Management Act, No 13 of 2005 (2005). The DMC functions under the Ministry of Disaster Management and Human Rights and the National Disaster Management Council (NDMC) (DMC, 2006). The disaster management institutions can be categorized according to three main hierarchical levels as national, district or intermediate level and local or divisional level. Each of above sectors has been awarded with different levels of authority by the said Act No 13 of 2005. The Figure 6 illustrates the inter-relationship of government and non government institutions with the DMC in order to carry out disaster mitigation and preparedness plans. Although the institutional arrangement is figured as follows, its involvement in disaster waste management is considerably less (DMC, 2006).

According to the Disaster Management Centre and Ministry of Disaster Management

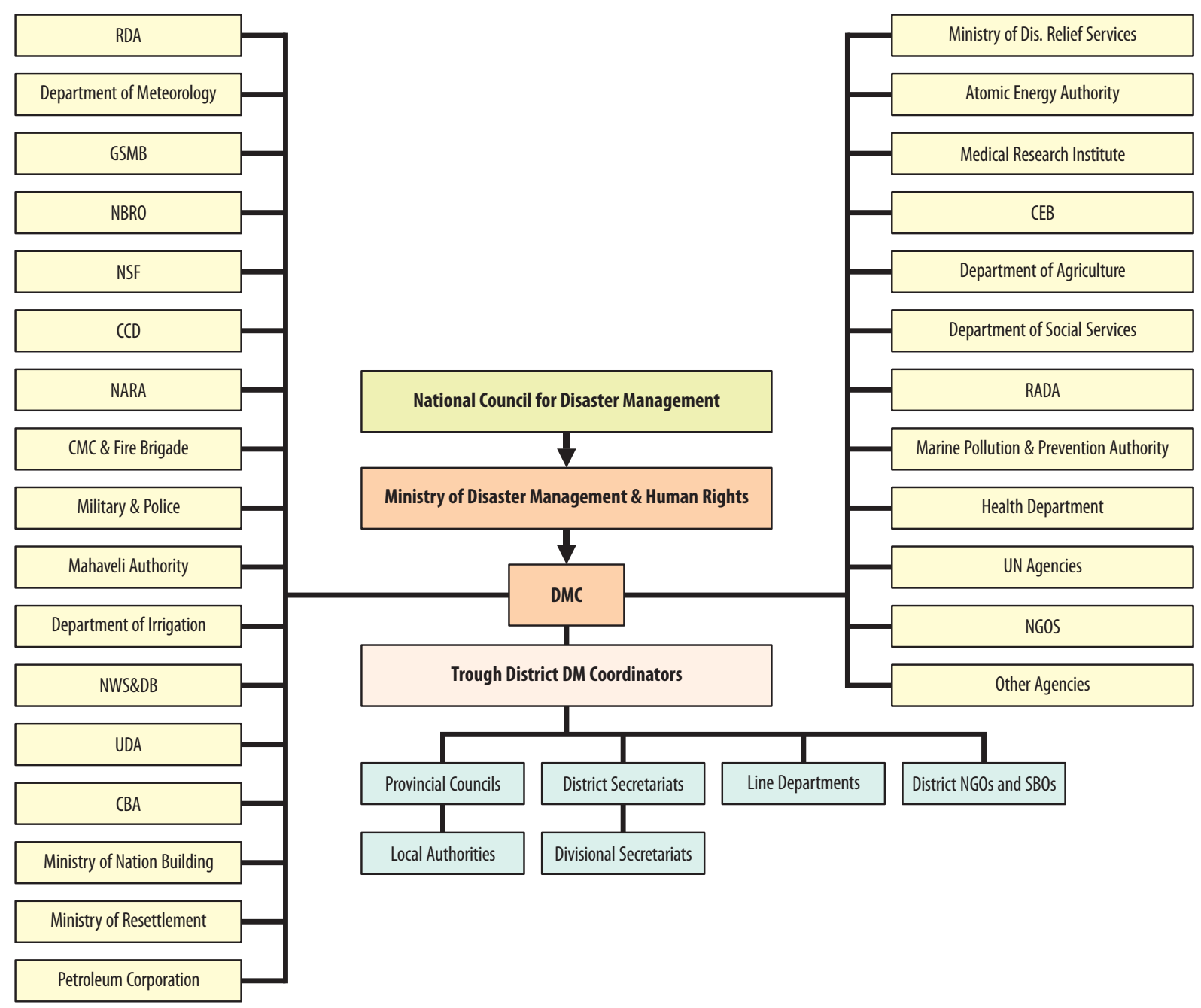

Figure 6. Stakeholders of disaster management cen Source: DMC (2006) 
and Human Rights (DMC, 2006), the national level institutions are involved in policy decision, resource allocation and prioritization of activities, budget allocation and monitoring of disaster management plans. All other disaster waste related activities are delegated to district level and regional level institutions. A summarized finding of pilot survey is illustrated at the Table 3 .

Results of the survey reveals that although there are national level polices for disaster management such as Disaster Management Act and national waste management policies, there are no provisions for disaster waste management. It only states that Disaster Management Council shall provide protection for environment and maintain and develop affected areas. Disaster Management Act, No 13 of 2005 (2005) and the National Environmental Act, No 47 of 1980 (1980) has regulated that persons should get a license from the Central Environmental Authority regarding collection, transportation, storing, recovering, recycling or disposing of waste. The Central Environmental Authority has been empowered by the act to specify guidelines regarding all operations of waste. But the act doesn't possess any framework for managing disaster waste. This situation proves that it is near impossible to have a specific disaster waste management industry in Sri Lanka.

\section{DISCUSSION}

The disasters affect the country in many ways (Alexander, 1997; Shaw and Goda, 2004). The costs of disasters are not just those caused to populations that suffer their direct impacts. The international image of a disaster-prone nation also suffers and inward investment can be affected, creating negative multiplier effects on jobs and wages throughout an economy. Disasters are first and foremost a major threat to development and specifically a threat to development of poorest and most marginalized people in the world. Disasters seek out the poor and ensure that they remain poor (Cherpitat, 2004 cited RICS, 2006). Therefore, disaster management strategies of both pre and post disaster scenarios should be adopted effectively to achieve development opportunities through out the dreadful results of disasters (Eceberger, 2006).

Table 3. Summarized findings of pilot survey

Institute Survey findings

Disaster Management Centre

Involve with pre disaster management activities such as preparation of plans for mitigation, preparedness and response phases from national level to regional levels. But there are no provisions for disaster waste management in any of the policies or plans.

Centsral Environment Authority

Marian Pollution and Prevention Authority

National Disaster Relief Center
Although CEA is the key national level organization for waste management, there are no special provisions for disaster waste management. Same rules and regulations applied for municipal waste management adopted for the same. Waste management strategies which need to implement will be decided after the disaster. Same principle applied when the Tsunami occurred and led to lot of environmental issues which are encountered even today such as frequent floods.

This is the only institute which prepared a disaster waste management plan, for oil spilling disaster situations in the sea.

Involved with all the post disaster management activities except waste management. 
To develop a coordinated, countrywide approach for managing disaster debris, implementation of a disaster management plan is essential. By planning ahead, disaster-related waste can be managed in a very environmentally sound manner, maximizing source reduction and recycling and minimizing land disposal of these materials (Alameda Country Waste Management Authority, 1998). A disaster debris management plan can help a community identify options for collecting, recycling and disposing of debris. Not only does a plan identify management options and sources for help, but it also can save valuable time and resources if it is needed. Survey revealed that there are no precise regulations in order to minimize generation of building waste resulting a disaster in the Sri Lankan context (UNEP, 2005). Only few regulations such as restrictions on buildings within $300 \mathrm{~m}$ distance from the sea shore has been imposed by the Coast Conservation Department. But it seems that those regulations also not observed properly by citizens. Main reason for failure of implementation of rules, strategies and plans is that at most instances they are dictated from top levels with minimal or zero input from people directly impacted. In addition, they are ill informed of realities of most peoples' lives and therefore, often unrealistic and prone to failure. As a result, unplanned disposal of waste in environmentally sensitive sites cause numerous problems since it consumes a considerable proportion of already scarce land filling sites.

Identification of disposal sites, possible recycling facilities, capacities of local areas and understanding of government and local authority structures to place responsibility for building waste management is not clearly distinguished in Sri Lanka. Specifically at national level, enforcement is lacking in policy making related to disaster waste management. However, rules and regulations connected to national solid waste management comprise of
National Environment Act, Predeshiya Sabha Act and Urban and Municipal Council Ordinances which also impose restrictions on management of waste. The National Environmental Act restricts dumping of solid waste into environmentally sensitive sites and provides for powers of the Central Environmental Authority (Perera, 2003). The local government Acts and Ordinances state that local authorities are responsible for proper removal of non- industrial solid waste and should provide proper sites for dumping of solid waste (Perera, 2003). Although the government enacted Disaster Management Act, No 13 of 2005 (2005) in May 2005 to provide a legal basis for disaster risk management (DRM) in the country, there are no provisions for management of disaster waste as previously discussed.

Apart from non-availability of institutional framework, lack of coordination and communication, non-availability of district and divisional contingency plans, political will and inadequate capacity are identified as key issues in disaster waste management in Sri Lanka (Hettiarachchi, 2007). For the individual in a developing country, losses resulting from disasters can be more severe in magnitude and take a much longer time to recover than a person in an industrialized nation (Ofori, 2004).

Lack of financial capability is a major contributing factor preventing a county from obtaining required physical resources such as equipment and infrastructure to launch successful long-term post disaster management programmes in developing countries. Within this context lack of intellectual capacity such as lack of knowledge, expertise and training related to post disaster management with relevant local authorities/ institutions is another key barrier in implementing sustainable disaster management programmes. The brain drain, lack of proper coordination between relevant authorities/ institutions and immature organizational processes can also be highlighted as issues of intellectually incapacitated countries 
(Keraminiyage et al., 2008). As Baycan and Petersen (2002) stated, "An important aspect of any intervention following natural disasters or conflicts is that of capacity building and employment generation". Identification of current capacity gaps is an essential task for Sri Lanka to overcome problems in post disaster waste management attempts. According to DMC current capacities of Sri Lankan institutions are inadequate for successful disaster management (JICA Study Team on comprehensive Disaster Management in Sri Lanka, 2007). Overall goal of the Disaster Management Centre of Sri Lanka is to mitigate damages cause by natural disasters in Sri Lanka by strengthening capacities of related organizations and communities. Capacity building is the best approach to a continuous process which delivers better services by developing and strengthening skills, instincts, abilities, processes and resources that organizations and communities need to survive, adapt, and thrive in a fast-changing world (Sivamainthan et al., 2008).

In national level disasters need to be understood as products of cumulative decisions taken over long periods, because then the processes by which these choices were made become a focal point for potential change (Campbell, 1999). Decisions taken in response to a specific disaster become defining elements for (temporary) resolution of that crisis, but also likely steps toward creation of the next crisis (Campbell, 1999). Therefore, disaster management should take place in a logical and practical manner to facilitate potential management of future disasters. Poulsen (2007) indicated that capacity building in waste management consists of following streams specifically at national level institutions:

- Elaboration of appropriate legislation and regulations.

- Development of effective and efficient scientific solutions and technology.

- Development and improvement of organizational structures.
- Appropriate training and practice that gives staff the right knowledge and tools to fulfill their jobs in an effective and efficient way.

To comply with above requirements, Disaster Management Act of Sri Lanka imposed capacity building among persons living in areas vulnerable to disasters in relation to risk management and application of disaster management and mitigation practices as main functions of the National Council for Disaster Management. However, according to annual report of NDMC 2006 (DMC, 2006), the DMC experienced difficulties in carrying out its task due to lack of legal power vested with it to implement. According to disaster management hierarchy, the DMC is the central regulatory body and all other national institutions lie under DMC. Therefore, enough legal powers are required by DMC to enforce powers granted by the Disaster Management Act. Furthermore, as indicated at NDMC Annual Report 2006 (DMC, 2006), it is suffering from incapacities on transport and communication, difficulties in recruiting staff, office accommodation and infrastructure development.

Building waste has a significant importance to ensure reconstruction by salvaging large amount of materials for reuse and recycle (Baycan and Petersen, 2002). Europe Aid Co-operation Office (2006) in their research has revealed that Sri Lankan reuse and recycling industry is limited only to demolition contractors and there are only eighteen known demolition and reuse contractors in Sri Lanka. Main obstacles for recycling building waste management are:

- It's relatively a new practice.

The country has used to remove all waste by disposing or land filling and there's great resistance to changing of such procedures.

- Limited recycling markets. Markets often either exists locally or re- 
cyclers don't accept a broader spectrum of building waste.

- Limited market awareness.

Many building contractors are not aware of reuse and recycling opportunities. Due to that, consumer willingness to buy recycled materials is very less.

- More costly.

This is due to high cost of some available recycling techniques.

- Require more space.

Recycling processes need more space for sorting, storage and recycling (RBAC, 2008).

Further, REA indicated that waste removal programs conducted at district levels with collaboration of NGOs do not consistently meet current best practices due to lack of readily available guidance, practical procedures and resources (Shaw, 2003; Martin, 2007).

Other critical issue in failure of waste management process is resistant to change. Most victims of the Tsunami are low-income less educated people living along coastal lines of Sri Lanka. Therefore, any significant social change needs to occur within context of their individual attitudes and behaviors (Shaw et al., 2003).

\section{CONCLUSIONS}

Disaster is not a new phenomenon and the human race, from its very appearance on this planet has faced the fury of natural hazards that has had devastating impacts towards communities and the environment. Although human loss is the true tragedy of a disaster, destruction of buildings and infrastructure can also be considered as a significant loss for the economy as well as the ecosystem. Those ruined buildings and infrastructure generate tre- mendous quantity of debris including rubble, concrete, bricks steel and timber which place an additional burden on a community to cope up with. Conversely, reconstruction of after a major disaster poses a tremendous challenge to any government as well as relevant community. Therefore, in rebuilding, the paramount consideration should be to building waste management strategies following any disaster situation.

Sri Lanka experiences a variety of disasters with immense damages to livelihoods, interrupting their economic and social activities. Among those, the Tsunami of December 2004, was the most devastating disaster Sri Lanka experienced in the recent past. Literature survey revealed that 450 , 000 tonnes of building waste was generated by the Tsunami in 13 districts in Sri Lanka. Further, it is well known that majority of those building debris were disposed in irregular ways creating number of environmental and social issues. Although other countries are having well planned waste management strategies, there are no specific policies or regulations regarding disaster waste management in Sri Lanka. Further, it revealed that controlling and collecting building waste in Sri Lanka is geared up less effectively because existing rules and regulations do not have legal enforceability or a mode to compel regular compliance. Further, building waste recycling projects have not been implemented in Sri Lanka due to lack of funds, plant and new technology, unfamiliarity and unawareness of recycled building materials etc. In brief, non-availability of institutional framework, lack of coordination and communication, nonavailability of district and divisional contingency plans, political will and inadequate capacity are identified as key issues related with disaster waste management in Sri Lanka. 


\section{REFERENCES}

Alameda County Waste Management Authority (1998) Alameda County Disaster Waste Management Plan. [Online] Alameda County Waste Management Authority with assistance from EMCON. Available at: http://www.stopwaste. org/docs/d-plan.pdf [accessed 13 June 2008]

Alexander, D. (1997) The study of natural disasters, 1977-1997: some reflections on a changing field of knowledge, Disasters, 21(4), pp. 284-304.

Aung, M. and Arias, M.L. (2006) Examining waste management in San Pablo del Lago, Ecuador: a behavioral framework, Management of Environmental Quality: An International Journal, 17(6), pp. 740-752.

Bandara, N.J.G.J. and Hettiarachchi, P.J. (2003) Environmental impacts associated with current waste disposal practices in a municipality in Sri Lanka - A case study. Workshop on Sustainable Landfill Management, Chennai, India, 3-5 December 2003, pp. 19-26.

Baycan, F. (2004) Emergency planning for disaster waste: a proposal based on the experience of the Marmara earthquake in Turkey. [Online] International Conference and Student Competition on post-disaster reconstruction "Planning for reconstruction", Coventry, UK, April 2223, 2004. Available at: http://www.grif.umontreal.ca/pages/papers2004/Paper\%20-\%20Baycan\%20F.pdf [accessed 21 August 2008]

Baycan, F. and Petersen, M. (2002) Disaster waste management-C\&D waste. In: ISWA, ed. Annual Conference of the International Solid Waste Association, 8-12 July 2002. Istanbul, Turkey, pp 117-125

Bekin, C., Carrigan, M. and Szmigin, I. (2007) Caring for the community an exploratory comparison of waste reduction behaviour by British and Brazilian consumers, International Journal of Sociology and Social Policy, 27(5/6), pp. 221-233.

Brodin, M.H. and Anderson, A. (2008) Recycling calls for revolution, Supply Chain Management-An International Journal, 13(1), pp. 9-15.

Campbell, D.J.V. (1999) Guest editorial: Institutional development for waste management in developing countries, Waste Management \& Research, 17(1), pp. 1-3.

CMRA (2008) Concrete recycling. [Online] Construction Materials Recycling Association (CMRA). Available at: http://www.concreterecycling.org [accessed 1 October 2008]
COWAM (2008) Strategy for Sustainable Construction and Demolition Waste Management in Galle, Sri Lanka. Interim Report: Vision for 2018. [Online] Available at: http://www.cowamproject.org/cms/Content/download/Interim_Report_Vision_2018.pdf [accessed 11 October 2008]

CRED (2007) Annual disaster statistical review: The numbers and trends. [Online] Center for Research on the Epidemiology of Disasters (CRED). Available at: http://www.preventionweb.net/files/1080_Annual20Disaster20Statistical20Review202006.pdf [accessed 12 January 2008]

de Boer, J.Z. and Sanders, D.T. (2004) Earthquakes in human history: The far-reaching effects of seismic disruptions. Princeton: Princeton University Press.

Disaster Management Act, No 13 of 2005 (2005) Published as a Supplement to Part II of the Gazette of the Democratic Socialist Republic of Sri Lanka of May 13, 2005. Colombo: Government publications bureau.

DMC (2005) Phases of the disaster. [Online] Disaster Management Centre (DMC). Available at: http://www.dmc.gov.lk [accessed 12 August 2008]

DMC (2006) Annual report 2006, Disaster Management Centre (DMC), Colombo.

DMC (2008) Towards a safer Sri Lanka - Road Map for Disaster Risk Management, Disaster Management Centre (DMC), Colombo.

Eceberger, D.L. (2006) How the sustainable solid waste management can be achieved in Sri Lanka, School of International Training in Colombo, Sri Lanka.

Eerland, D.W. (1995) Experience with the construction and demolition waste recycling in the Netherlands - Its application to earthquake waste recycling in Kobe. In: IETC, ed. International Symposium on Earthquake Waste, 12-13 June 1995, Osaka. Shiga: UNEP, pp.72-85.

EM-DAT (2008) EM-DAT: Emergency Events Database. [Online] Center for Research on the Epidemiology of Disasters (CRED). Available at: http://www.emdat.be/Database/terms.html

EPA (2008) Planning for disaster debris. [Online] United States Environmental Protection Agency (EPA). Available at: http://www.epa.gov/ osw/conserve/rrr/imr/cdm/pubs/disaster.htm [accessed 25 August 2008] 
Europe Aid Co-operation Office (2006) Construction waste management in Sri Lanka. [Online] Available at http://www.cowam-project.org [accessed 22 September 2008]

EC (2006) Progress report on Post Tsunami rehabilitation and reconstruction program. [Online] European Commission (EC). Available at: http://ec.europa.eu/comm/world/tsunami/index. htm [accessed 5 August 2008]

FEMA (2007) Public assistance: Debris management guide, Federal Emergency Management Agency (FEMA). Washington: FEMA.

Harvey, P. (2005) Cash vouchers in Emergencies, London: Overseas Development Institute.

Helmer, D. and Hihorst, D. (2006) Natural disasters and climate change, Disasters, 30(1), pp. 1-4.

Hettiarachchi, N. D (2004) National Disaster Management Policy - Implications for Regional Development, Proceedings of the Workshop on Regional Development Experience in $S L$, Sri Lanka, 13-14 August 2004.

Hettiarachchi, N.D. (2007) Disaster Management in Sri Lanka: Mobilizing Response Measures during Disasters, avoiding Human Misery. National Relief Services Center and Ministry of Resettlement and Disaster Relief Services. [Online] Available at: http://www.lankajalani. org/Publications/Disaster\%20ManagementN.\%20D.\%20Hettiarachchi.ppt\#1 [accessed 17 June 2008]

IFRC and RCS (2000) Disaster data: Key to improved response. [Online] International Federation of Red Cross and Red Crescent Societies. Available at: http://www.ifrc.org/publicat/ wdr2000/ [accessed 25 August 2008]

Jayawardane, A.K.W. (2006) Disaster mitigation initiatives in Sri Lanka. [Online] University of Moratuwa. Available at: http://management. kochi-tech.ac.jp/PDF/IWPM/IWPM_Jayawardane.pdf [accessed 17 June 2007]

Jayaweera, S. (2006) Impacts of Landslides due to Land Degradation Consequence of Unplanned Human Settlements Development in Hill Slopes of Sri Lanka. [Online] National Building Research Organization. Available at: http://www. lankajalani.org/Publications/Impact $\% 20$ of $\% 20$ Landslides-sunil\%20jayaweera.doc [Accessed 25 August 2008]

JICA Study Team on comprehensive Disaster Management in Sri Lanka. (2007) Launching of Comprehensive Disaster Management Study in Sri Lanka. SLDM MIND, [Online] March. Available at: http://www.dmc.gov.lk/jica/index. html [Accessed 13 June 2008]

Joint Report (2005) Sri Lanka Post Tsunami Recovery and Reconstruction - progress, challenges and way forward, Joint Report of the Government of Sri Lanka and Development Partners, Colombo: Ministry of Finance and Planning.

Keraminiyage, K. Amaratunga, A. and Haigh, R. (2008) Post tsunami recovery Capacity gaps in Sri Lanka. Building Resilience, 11-15 ${ }^{\text {th }}$ Feb., Sri Lanka, pp. 1011-1022.

Kobayashi, Y. (1995) Disasters and the problems of wastes. In: IETC, ed. International Symposium on Earthquake Waste, 12-13 June 1995 Osaka. Shiga: UNEP, pp. 6-13.

Kourmpanis, B., Papadopoulos, A., Moustakas, K., Stylianou, M., Haralambous, K.J. and Lolijodou, M. (2008) Preliminary study for the management of construction and demolition waste, Waste Management \& Research, 26(3), pp. 267-275.

Lindell, M.L. and Prater, C.S. (2003) Assessing community impacts of natural disasters, Natural Hazards Review, 4(4), pp. 176-185.

Martin, N. (2007) The Asian Tsunami: An urgent case for improved government information systems and management, Disaster Prevention and Management, 16(2), pp. 188-200.

National Environmental Act, No 47 of 1980 (1980) Colombo: Government publications bureau.

Ofori, G. (2004) Construction in Disaster Management. [Online] National University of Singapore. Available at: http://buildnet.csir.co.za/ cdcproc/docs/3rd/ofori02.pdf [accessed 20 June 2008]

Pelling, M., Ozerdem, A. and Barakat, S. (2002) The macro economic impact of disasters, Progress in Development Studies, 2(4), pp. 283-305.

Peng, C.L., Scorpio, D.E. and Kibert, C.J. (1997) Strategies for successful construction and demolition waste recycling operations, Construction Management and Economics, 15(1), pp. 49-58.

Peppiatt, D., Mitchell, J. and Holzmann, P. (2001) Cash transfers in Emergencies: Evaluating Benefits and Assessing risks, HPN Network paper No. 35, Overseas Development Institute, London.

Perera, K.L.S. (2003) An overview of the issue of solid waste management of Sri Lanka. In: 
Bunch, M.J. (Ed.) $3^{\text {rd }}$ International conference on environment and health, 15-17 December 2003 India. Chennai: University of Madras, pp. 346-352.

Petersen, M. (2004) Restoring waste management following disasters. In: IF, ed. International conference on post disaster reconstruction, 22-23 April 2004, UK. Coventry: IF Research group.

Pilapitiya, S., Vidanaarachchi, C. and Yuen, S. (2006) Effects of the tsunami on waste management in Sri Lanka, Waste Management, 26(2), pp. 107-109.

Poulsen, S.B. (2007) Report: Examples of capacity building cooperation, Waste Management \& Research, 25(3), pp. 283-287.

Practical Action (2008) Planning for municipal solid waste management. [Online] The Schumacher Centre for Technology and Development, UK. Available at: http://www.practicalaction.org [accessed 23 September 2008]

Rafee, N., Karbassi, A.R., Nouri, J., Safari, E. and Mehrdadi, M. (2008) Strategic management of municipal debris aftermath of an earthquake, International Journal of Environmental Research, 2(2), pp. 205-214.

RBAC (2008) Recycling business assistance. [Online] Recycling Business Assistance Centre (RBAC). Available at: http://www.p2pays.org/rbac/ [accessed 23 September 2008]

RICS (2006) Mind the Gap: Post disaster reconstruction and the transition from humanitarian relief, London: RICS.

Selvendran, P.G. and Mulvey, C. (2005) Reducing solid waste and groundwater contamination after the tsunami, Daily news, Tuesday, 15 February, 2005.

Shaw, R. (2003) Role of non-government organizations in earthquake disaster management: on Asian perspective, Regional Disaster Dialogue, 24(1), pp. 117-129.
Shaw, R. and Sinha, R. (2003) Towards sustainable recovery: future challenges after Gujarat earthquake, Risk Management, 5(3), pp. 35-51.

Shaw, R., (2006) Indian Ocean tsunami and aftermath: need for environment-disaster synergy in the reconstruction process, Disaster Prevention and Management, 7(1), pp. 5-20.

Shaw, R., and Goda, K. (2004) From disaster to sustainable civil society: the Kobe experience, Disaster, 28(1), pp. 16-40.

Shaw, R., Gupta, M. and Sharma, A. (2003) Community recovery and its sustainability: lessons from Gujarat earthquake in India, The Aus tralian Journal of Emergency Management, 18(2), pp. 28-34.

Sivamainthan, K., Manewa, A. and Seneviratne, I. (2008) Capacity Building: A Framework for the Built Environment Education. In: Haigh, R. and Amaratunga, D. (Eds.) Proceedings of the CIB International Conference on Building Education and Research "Building Resilience", Heritance Kandalama, Sri Lanka, 11th - 15th February 2008. School of the Built Environment, University of Salford, UK, pp. 530-538.

Stone, R. (2008) Sichuan disaster: Landslides, Flooding Pose Threats as Experts Survey Quake's Impact, Science, 320(5879), pp. 996-997.

Subasinghe, S.A.D.A. (2005) The tsunami disaster a real challenge to our members, Sri Lanka Engineering News, December/January, p. 1.

The Kindred Association (1994) A practical recycling handbook. London: Thomas Telford Services Ltd.

Treloar, G.J., Gupta, H., Love, P.E.D. and Nguyen, B. (2003) An analysis of factors influencing waste minimization and use of recycled materials for the construction of residential buildings, Management of Environmental Quality, 14(1), pp. 134-145.

UNEP (2005) Sri Lanka post tsunami environmental assessment, United Nation Environment Program (UNEP). Geneva: UNEP, (DEP/0758/GE). 


\section{SANTRAUKA}

\section{ATLIEKŲ TVARKYMO PO STICHINIŲ NELAIMIŲ STRATEGIJOS BESIVYSTANČIOSE ŠALYSE: ŠRI LANKOS ATVEJIS}

\section{Gayani KARUNASENA, Dilanthi AMARATUNGA, Richard HAIGH, Irene LILL}

Stichinès nelaimès visame pasaulyje pridaro daug žalos. Tai labai pasunkina aplinkosauginę ir ekonominę situacija iprastomis gyvenimo salygomis, atstatant aplinką ir vykdant bendruosius atlieku rinkimo procesus. Šiame kontekste atliekų tvarkymas išryškejjo kaip esminè problema, reaguojant i stichinę nelaimę. Taigi šiame darbe nagrinejjamos atlieku tvarkymo po stichiniu nelaimių strategijos, taikomos besivystančiose šalyse, ir geriausiu pasauliniu praktiku taikymas, imantis kilusių iššūkių. Siekiant surinkti informacija, išsamiai apžvelgta literatūra ir tiesiogiai ištirtos Šri Lankos valstybinès institucijos, o duomenims rinkti pasitelktas pusiau struktūriniu interviu metodas. Iš rezultatų aišku, kad strategijos, problemos ir iššūkiai skiriasi priklausomai nuo stichinès nelaimės pobūdžio, masto, vietos, valstybės ir pan. Be to, nustatyta, kad pagrindinès problemos yra prastas visuotiniu taisykliu ir reglamentų taikymas, prasti vietinès patirties standartai ir menkos galimybès, lèšų trūkumas, komunikacijos ir koordinavimo trūkumas. 